\title{
Some Hazards of the Sweat Test
}

\author{
V. SCHWARZ, C. H. SUTCLIFFE, and PATRICIA P. STYLE \\ From the Departments of Medical Biochemistry and Child Health, University of Manchester
}

The comparatively high incidence of cystic fibrosis (CF) and the importance of early diagnosis have afforded the sweat test the status of a routine procedure at all children's hospitals. The bag test, which relied on uncontrolled heating of the patient, was recognized as being potentially dangerous and gave way to pilocarpine stimulation. Though variants of this test have been in use for several years, its hazards to the patients have not been investigated thoroughly, nor do the sources of error enjoy the widespread recognition merited by a major diagnostic tool. We present some of our findings in the hope that they may increase the reliability of the test and help to spare the patient needless pain.

The passage of a current through the body carries the risk of ventricular fibrillation, respiratory arrest, asphyxia (Lee, 1966), burns, and blistering. The lowest voltage fatality in man, recorded by Kouwenhoven (1949), occurred with an alternating current of 60 cycles and a voltage of $46 \mathrm{v}$. While the chance of a serious effect on the heart, respiratory centre, or muscles by a direct current (normally less dangerous than alternating current) of a few milliamps is small, a current of $50 \mathrm{~mA}$, when passed from one fore-limb of a rabbit to the other, has been reported to produce respiratory arrest by tetanic contraction of the respiratory muscles (Angelis, Lee, and Zoledziowski, 1965).

Burns and blisters are a much more common hazard. We have seen children with deep burns, suffered during a previous sweat test, who were terrified when faced with another test. Contrary to the view expressed by Shwachman and Antonowicz (1962), burns do not necessarily or exclusively result from direct contact of the electrode with the skin.

The experiments reported below were carried out to pin-point the circumstances in which a small current passed through the skin produces burns and blisters.

Received June 26, 1968.

\section{Effect of Direct Contact of Electrode with Skin}

A carbon or copper electrode, $1 \times 1 \mathrm{~cm}$., was placed on the lower forearm of a healthy adult, either in contact with the skin or with 8 filter paper squares interposed. In all cases adequate electrical conductivity was ensured by a solution of pilocarpine nitrate $(0.45 \%)$. Direct or rectified alternating currents (as produced by the kit recommended by Shwachman) of 1 or $1.5 \mathrm{~mA}$ per sq. $\mathrm{cm}$. were passed for 4 minutes through this positive electrode to a negative electrode placed above the elbow. These current densities were far in excess of that used in the usual test $\left(0.07 \mathrm{~mA} / \mathrm{cm}^{2}\right.$ ) (Shwachman and Antonowicz, 1962). No burns or blisters were produced in any of these experiments provided that plenty of electrolyte was present.

\section{Skin Resistance With and Without Inter- posed Filter Paper}

The skin resistance was measured on the forearm of a healthy adult using an Avometer and a $1 \times 1$ $\mathrm{cm}$. carbon or copper anode either in direct contact with the skin or with 8 filter paper squares $(1 \times 1$ $\mathrm{cm}$.) interposed, electrical contact being ensured by a solution of pilocarpine nitrate. The cathode was a bandage, moistened with $\mathrm{KCl}$ solution, wrapped round the upper arm. The resistance was 20,000 and 16,000 ohms, respectively. There are thus no grounds for believing that the resistance will be smaller and hence more current will flow through the site of direct contact between the skin and the electrode than through the material soaked in electrolyte solution.

\section{Effect of Blistering on Skin Resistance}

Since the skin resistance is known to depend largely on the functional state of the sweat glands, atropine was passed by iontophoresis in the usual manner into an area of skin $3 \times 3 \mathrm{~cm}$., using a direct current of $4 \mathrm{~mA}$ for 5 minutes. Pain was 
experienced by the subject, and at the end of the iontophoretic administration of the drug a cluster of small 'pits' was found on the site. These were soon engulfed in an oedematous swelling about 4-5 cm. ${ }^{2}$ in area. The skin resistance was measured using a $1 \times 1 \mathrm{~cm}$. carbon electrode (i) over the swelling, (ii) within the apparently unaffected atropinized area, and (iii) outside the atropinized area. The following values were found: (i) 1000 ohms, (ii) 40,000-100,000 ohms, (iii) $25,000-40,000$ ohms.

In other experiments the skin resistance over blisters fell to almost zero. Thus blistering can lead to a 100 - to 1000 -fold reduction in skin resistance, which could result in a greatly increased current density in the oedematous area.

\section{Effect of Firmness of Contact}

A carbon anode $1 \times 1 \mathrm{~cm}$. was applied directly to 3 sites on the skin of the forearm of a healthy adult (using pilocarpine solution as electrolyte and a direct current of $1 \mathrm{~mA}$ ) in the following manner: (i) and (ii) with the electrode firmly pressed on to the skin, (iii) with the electrode in only loose contact with the skin in the presence of ample electolyte which was kept mixed by a gentle to-and-fro motion of the electrode. After two minutes, sites (i) and (ii) showed several blisters, while site (iii) had none. This observation suggested that blistering might be caused by the products of electrolysis accumulating near the skin surface.

\section{Effect of Acid}

Small squares, approximately $2 \times 2 \mathrm{~mm}$., were cut off one corner of a stack of 4 filter papers $(1 \times 1 \mathrm{~cm}$.). The large squares were soaked in a solution of pilocarpine nitrate while the small squares were soaked in $\mathrm{HCl}$ of various normalities. The two stacks were then placed on the skin in jigsaw fashion, covered by another 8 squares $1 \times 1 \mathrm{~cm}$., moistened with pilocarpine solution. A carbon anode was placed on top of the pile and a current of $2 \mathrm{~mA}$ was passed for 2 minutes. (The cathode was a bandage, moistened with $\mathrm{KCl}$ solution, above the elbow.) The appearance of the skin in each case, noted at the end of this time, is presented in Table I.

In a second series of experiments, the effect of different thicknesses of filter paper pad $(1 \times 1$ $\mathrm{cm}$.) interposed between the electrode and the skin was investigated. The electrolyte was $\mathrm{KCl}$ (the pilocarpine solution and the $2 \times 2 \mathrm{~mm}$. cutout used in the previous experiment were omitted), and the current was $2 \mathrm{~mA}$, applied for 2 minutes,
TABLE I

Effect of Acid on Skin During Iontophoresis

\begin{tabular}{c|l}
\hline $\begin{array}{c}\text { Normality of } \mathrm{HCl} \\
\text { on Small Square }\end{array}$ & \multicolumn{1}{c}{ Observation } \\
\hline 0.1 & $\begin{array}{l}\text { Blister in area under small square only } \\
0.05\end{array}$ \\
0.02 & $\begin{array}{l}\text { Blister in area under small square only } \\
\text { Blister in area under small square only } \\
0.01\end{array}$ \\
0.003 & $\begin{array}{l}\text { Blister in area under small square only } \\
\text { No blisters anywhere }\end{array}$ \\
\hline
\end{tabular}

TABLE II

Effect of Thickness of Filter Paper Pad on Acidity Next to Skin, Blister Formation and Sensation Felt by Subject

\begin{tabular}{|c|c|c|c|}
\hline $\begin{array}{l}\text { No. of Papers } \\
\text { in Pad }\end{array}$ & $\begin{array}{c}\text { pH of } \\
\text { Filter Paper }\end{array}$ & $\begin{array}{l}\text { Appearance of } \\
\text { Skin }\end{array}$ & $\begin{array}{c}\text { Sensation felt } \\
\text { by Subject }\end{array}$ \\
\hline $\begin{array}{r}12 \\
9\end{array}$ & $\begin{array}{l}\text { pH } 7 \\
\text { pH } 2 \text { near one } \\
\text { edge }\end{array}$ & $\begin{array}{l}\text { No blisters } \\
3 \text { small blisters } \\
\text { under acid } \\
\text { edge of } \\
\text { paper }\end{array}$ & $\begin{array}{l}\text { None } \\
\text { None }\end{array}$ \\
\hline 6 & $\begin{array}{l}\text { pH } 2 \text { around } \\
\text { periphery }\end{array}$ & No blisters & None \\
\hline 4 & $p \bar{H}<2$ & $\begin{array}{l}1 \text { pit and } 5 \\
\text { small } \\
\text { blisters }\end{array}$ & Very painful \\
\hline 3 & $p H<2$ & $\begin{array}{l}4 \text { small } \\
\text { blisters }\end{array}$ & Very painful \\
\hline
\end{tabular}

using a carbon electrode. The paper closest to the skin was tested for acid with indicator paper and the appearance of the skin and the sensation felt by the subject were noted (Table II).

Next, the effect of iontophoresing buffers of different $p \mathrm{H}$, both at the anodic and cathodic side, was studied, using $0 \cdot 1 \mathrm{~N}$ citrate or $\mathrm{HCl} / \mathrm{NaCl}$ / glycine buffer, a $1 \times 1 \mathrm{~cm}$. carbon electrode, 8 filter paper squares, and a current of $1 \mathrm{~mA}$, for 5 minutes. The other electrode was the bandage above the elbow in each case (Table III). When filter paper moistened with $0 \cdot 1 \mathrm{~N} \mathrm{HCl}$ was applied to the skin for 5 minutes without a current being passed, no pain or blisters were elicited.

\section{Generation of Acid During Iontophoresis of Pilocarpine Nitrate}

A solution of pilocarpine nitrate $(0.45 \%)$ was used to moisten 12 filter papers $(3 \times 3 \mathrm{~cm}$.) interposed between a carbon anode and the skin. A current of $4 \mathrm{~mA}$ was passed for 5 minutes. There was minimal pain and no blisters were found. The papers were separated into adjacent pairs and shaken in $1 \mathrm{ml}$. water in a test-tube to elute 
TABLE III

Effect of $\mathrm{pH}$ on Blister Formation

\begin{tabular}{|c|c|c|c|}
\hline \multirow{2}{*}{ Buffer } & \multirow{2}{*}{$p \mathrm{H}$} & \multicolumn{2}{|c|}{ Observations } \\
\hline & & Anode & Cathode \\
\hline $\begin{array}{l}\text { Citrate } \\
\text { Citrate }\end{array}$ & $\begin{array}{l}8 \cdot 0 \\
7 \cdot 0\end{array}$ & - & $\begin{array}{l}\text { No pain, no blisters } \\
\text { No pain, } 3 \text { minute }\end{array}$ \\
\hline Citrate & $6 \cdot 0$ & 一 & $\begin{array}{l}\text { blisters } \\
\text { Little pain, few } \\
\text { minute blisters }\end{array}$ \\
\hline $\begin{array}{l}\text { Citrate } \\
\text { Citrate }\end{array}$ & $\begin{array}{l}5 \cdot 0 \\
4 \cdot 0\end{array}$ & Ne pain $\bar{n}$ oblisters & \\
\hline Citrate & $3 \cdot 0$ & $\begin{array}{l}\text { Very mild pain, no } \\
\text { blisters }\end{array}$ & \\
\hline Citrate & $2 \cdot 6$ & $\begin{array}{l}\text { Very mild pain, no } \\
\text { blisters }\end{array}$ & $\begin{array}{l}\text { Moderately painful, } \\
\text { several small }\end{array}$ \\
\hline Citrate & $2 \cdot 2$ & $\begin{array}{l}\text { Little pain, } 6 \text { small } \\
\text { blisters }\end{array}$ & blisters \\
\hline Citrate & $2 \cdot 2$ & $\begin{array}{l}\text { Stinging pain, } \\
\text { several blisters } \\
\text { and pits }\end{array}$ & \\
\hline $\mathrm{HCl} /$ glyc. & $2 \cdot 4$ & $\begin{array}{l}\text { Minimal discomfort, } \\
\text { no blisters }\end{array}$ & \\
\hline $\mathrm{HCl} /$ glyc. & $2 \cdot 0$ & $\begin{array}{l}\text { Very little discom- } \\
\text { fort, no blisters }\end{array}$ & \\
\hline $\mathrm{HCl} /$ glyc. & $1 \cdot 6$ & $\begin{array}{l}\text { Very little discom- } \\
\text { fort, no blisters }\end{array}$ & \\
\hline $\mathrm{HCl} /$ glyc. & $1 \cdot 6$ & $\begin{array}{l}\text { Slight stinging, } 8 \\
\text { small pits }\end{array}$ & $\begin{array}{l}\text { No discomfort, no } \\
\text { blisters }\end{array}$ \\
\hline $\mathrm{HCl} /$ glyc. & $1 \cdot 2$ & $\begin{array}{l}\text { Stinging pain, } 15 \\
\text { small pits }\end{array}$ & \\
\hline $\mathrm{HCl} /$ glyc. & $1 \cdot 2$ & $\begin{array}{l}\text { Stinging pain, } \\
\text { several pits }\end{array}$ & \\
\hline $\mathrm{HCl} / \mathrm{glyc}$. & $1 \cdot 2^{\star}$ & $\begin{array}{l}\text { Stinging pain, } \\
\text { several pits }\end{array}$ & \\
\hline
\end{tabular}

All observations with the exception of one (*lead electrode) were made using a carbon electrode.

the electrolytes. The $p \mathrm{H}$ was then measured with a glass electrode (Table IV).

The experiment was repeated using only 4 papers. A stinging pain during iontophoresis and 2 pits in the skin were noted (Table V).

Next, the effect of the chloride ion was compared with that of the nitrate ion, using $0.9 \% \mathrm{NaCl}$ and $1 \cdot 2 \%$ (isotonic) $\mathrm{NaNO}_{3}$ solutions on 4 filter paper squares. In both cases a slight stinging was felt during iontophoresis, which was carried out as above (Table VI).

Since the distribution of acid in the paper pile might not be uniform, the iontophoresis of pilocarpine nitrate was repeated using only 2 barely moist filter paper squares and a current of $4 \mathrm{~mA}$ for 5 minutes. This elicited a stinging pain and a group of blisters. On completion of the iontophoresis the 2 papers were sprayed separately with an alcoholic solution of thymol blue which gives a faint to strong pink at $p \mathrm{H}$ values between $2 \cdot 6$ and $2 \cdot 2$. The intensity of the pink colour on the 2 paper squares and the position of the blisters on the skin are shown in Fig. 1.
TABLE IV

Penetration of Acid Through a Stack of 12 Filter Papers

\begin{tabular}{|c|c|c|c|c|c|}
\hline \multicolumn{5}{|c|}{ Papers } & $\frac{p \mathrm{H}}{5.90}$ \\
\hline $\begin{array}{l}1 \text { and } 2 \text { (r } \\
3 \text { and } 4 \\
5 \text { and } 6 \\
7 \text { and } 8 \\
9 \text { and } 10 \\
11 \text { and } 12\end{array}$ & $\begin{array}{l}\text { to } \\
\ldots \\
\ldots \\
\cdots \\
\ldots \\
x t\end{array}$ & $\begin{array}{l}\text { n) } \\
\ldots \\
\ldots \\
\ldots \\
\ldots \\
\text { ectr }\end{array}$ & $\begin{array}{l}\ldots \\
\ldots \\
\ldots \\
\ldots \\
.\end{array}$ & $\begin{array}{l}\ldots \\
\ldots \\
\ldots \\
\ldots \\
\ldots\end{array}$ & $\begin{array}{l}5 \cdot 90 \\
5 \cdot 15 \\
4 \cdot 70 \\
4 \cdot 38 \\
4 \cdot 23 \\
4 \cdot 21\end{array}$ \\
\hline
\end{tabular}

TABLE V

Penetration of Acid Through 4 Filter Papers

\begin{tabular}{ccc|c}
\hline \multicolumn{1}{c|}{ Papers } & & pH \\
\hline 1 and 2 (next to skin) &. &.. & $3 \cdot 18$ \\
3 and 4 (next to electrode) &. &.. & $3 \cdot 17$ \\
\hline
\end{tabular}

TABLE VI

Penetration of Acid Generated from Chloride and Nitrate

\begin{tabular}{l|c|c}
\hline \multirow{2}{*}{ Papers } & \multicolumn{2}{|c}{$p \mathrm{H}$} \\
\cline { 2 - 3 } & $(\mathrm{NaCl})$ & $\left(\mathrm{NaNO}_{3}\right)$ \\
\hline 1 and 2 (next to skin) & $3 \cdot 68$ & $3 \cdot 29$ \\
3 and 4 (next to electrode).. & $3 \cdot 43$ & $3 \cdot 22$ \\
\hline
\end{tabular}

On repeating this experiment in an identical manner, but using 5 paper squares instead of 2 , the subject again experienced a stinging pain and the pattern of the blisters was found to correspond closely to the areas of low $p \mathrm{H}(<2 \cdot 6)$ on the paper square next to the skin (Fig. 2).

Finally, 12 papers were interposed between the electrode and the skin, as in the first experiment of this series, but after iontophoresis the papers were sprayed with thymol blue. No pain was felt by the subject, there were no blisters, and the
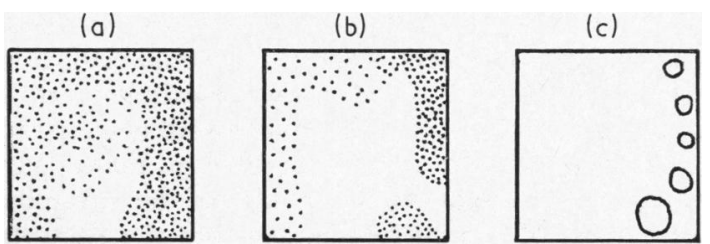

Fig. 1.-Areas of low $\mathrm{pH}(2 \cdot 2-2 \cdot 6)$ on 2 paper squares, (a) near electrode, (b) near skin, and (c) pattern of blisters. 
(a)

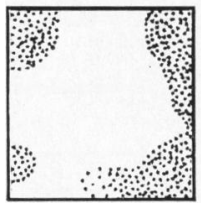

(b)

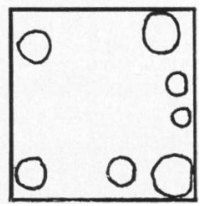

Fig. 2.-Areas of low $\mathrm{pH}$ on paper square (a), and pattern of blisters $(\mathrm{b})$.

colour of the paper squares varied from bright pink at the electrode end of the pile to yellow $(p \mathrm{H}$ greater than $2 \cdot 8)$ next to the skin. A trace of pink was visible on the third square (tenth from electrode).

\section{Comparison of Carbon, Lead, and Copper Anodes}

The three electrodes were compared with respect to generation of acid during electrolysis, using, in each case, a stack of 12 filter paper squares $(3 \times 3$ $\mathrm{cm}$.), moistened with $1.2 \mathrm{ml}$. pilocarpine nitrate solution, and a current of $4 \mathrm{~mA}$ for 5 minutes. Individual squares were tested for $\mathrm{pH}$ and the relevant metal ion.

With the carbon electrode, the papers showed increasing acidity from the second square (trace) to the electrode.

The lead electrode produced no acidity below pH 3.5 on any square, but lead was found from the fourth square (trace) to the twelfth (heavy).

With the copper electrode, acid was detected on papers 7 to 12 , none closer to the skin, but copper was present in increasing amounts from square 2 (trace) to the electrode.

\section{Migration of Lead During Iontophoresis}

When a lead electrode was employed as the anode and 12 papers, moistened with pilocarpine nitrate, were interposed between the electrode and the skin, and a current of $4 \mathrm{~mA}$ was passed for 6 minutes, lead was found on the paper squares as indicated in Table VII (method of Kench, 1940). The amount of lead which would pass into the skin if only 4 papers were used would probably be over $200 \mathrm{\mu g}$. Uniformly distributed in a skin slice $9 \mathrm{~cm} .{ }^{2} \times 0.2 \mathrm{~cm}$., this would correspond to a concentration of $11 \mathrm{mg} . / 100 \mathrm{~g}$. tissue. In practice the distribution would not be uniform, since most of the current passes into the skin via the sweat ducts and hence the local concentration could be much higher.

\section{Reliability of Sweat Test}

A different kind of hazard is presented by faulty execution of the sweat test. Inadequate sealing of the absorbent pad to the skin or delay in transferring it to the weighing bottle results in evaporation of water and hence in an apparently higher concentration of sodium chloride.

In an experiment to determine the rate of evaporation of water from an unprotected square of filter paper, $3 \times 3 \mathrm{~cm}$., in average laboratory conditions (ambient temperature $20^{\circ} \mathrm{C}$.) the loss of water was $0.87 \pm 0.52(\mathrm{SD}) \mathrm{mg}$. in 5 seconds $(\mathrm{n}=4)$.

Another potential source of serious error is contamination of the collection pad with sodium chloride from the technician's hands or with the patient's extracellular fluid oozing from a small wound or blister.

Lastly, account must be taken of the secretory rate, the influence of which on the sodium concentration of sweat (and of saliva) has been stressed by many investigators. The sweat from CF children can, by its high sodium content, be unequivocally differentiated from normal children's sweat over a fairly wide range of rates. This does not hold for adults, and even in CF children the sweat secreted at low rates has sodium concentrations within the normal range, as will be apparent from the experiments reported below.

A filter paper (Whatman $541,3 \times 3 \mathrm{~cm}$.), previously weighed, was placed on the subject's carefully washed and dried forearm, covered with a square of thin plastic of the same size, and secured to the skin by four strips of elastic Sellotape. After 90 to 120 minutes the 'chamber' was opened on one side by pulling back the adhesive tape, the paper was quickly withdrawn by means of forceps and placed in the weighing bottle for reweighing. Between 5 and $10 \mathrm{mg}$. of 'sweat' was collected from 9 control and 4 fibrocystic children, corresponding to mean apparent secretory rates of 0.31 and $0.34 \mathrm{mg} . / 9 \mathrm{~cm} .{ }^{2}$ per $5 \mathrm{~min}$., respectively. It was deemed desirable to correct these very low secretion rates for invisible perspiration which would be absorbed as vapour by the filter paper and thus contribute to the

TABLE VII

Penetration of Lead Through Stack of Filter Papers

\begin{tabular}{rrrr|c}
\hline \multicolumn{3}{c|}{ Square No. } & & Lead $(\mu \mathrm{g})$. \\
\hline (Skin) & 1 and 2 & $\ldots$ & $\ldots$ & $10 \cdot 2$ \\
3 and 4 & $\ldots$ & $\ldots$ & $33 \cdot 7$ \\
5 and 6 & $\ldots$ & $\ldots$ & $60 \cdot 5$ \\
7 and 8 & $\ldots$ & $\ldots$ & 110 \\
9 and 10 & $\ldots$ & $\ldots$ & 383 \\
(Electrode) 11 and 12 & $\ldots$ & $\ldots$ & 1485 \\
\end{tabular}




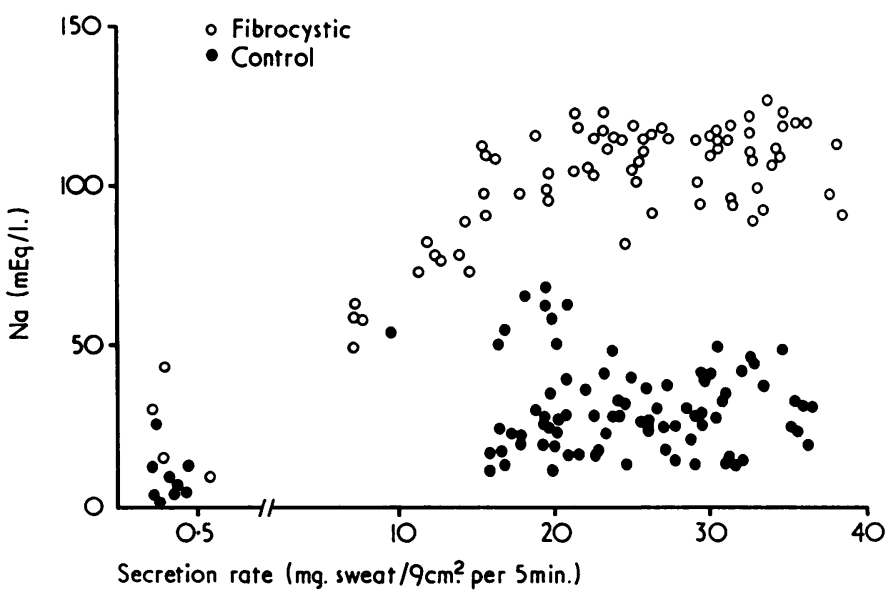

FIG. 3.-Dependence of sweat sodium concentration on secretion rate.

weight of sweat. The amount deducted was based on an estimated vapour loss of $1.8 \mathrm{mg} . / 9 \mathrm{~cm} .{ }^{2}$ per $\mathrm{hr}$. (Rosenberg, Blank, and Resnik, 1962). After eluting the sweat from the paper squares, the sodium was determined by a flame photometer (EEL, modified to increase sensitivity and precision), and the sodium concentration was calculated on the basis of the corrected weight of sweat collected.

Fig. 3 shows the sodium concentrations of stimulated and unstimulated sweat, collected from children of various ages, plotted against secretion rate. The overlap of $\mathrm{Na}$ concentrations of normal and $\mathrm{CF}$ sweat at secretion rates below $15 \mathrm{mg} . / 9 \mathrm{~cm} .^{2}$ per $5 \mathrm{~min}$. is apparent. (The lowest secretion rates represent spontaneous unstimulated sweating.)

Incomplete elution of sweat from the collection paper for the determination of sodium or chloride can be another source of serious error. The efficiency of the procedure was tested as follows. Known amounts of standard sodium chloride solution were placed on paper squares (Whatman $541,3 \times 3 \mathrm{~cm}$.). The ions were then extracted either chromatographically (Fig. 4), or by soaking the squares in water for varying periods. The latter method gave low recoveries, and cellulose fibres in the extract interfered with the flame photometry. The perfectly clear eluent obtained by the chromatographic procedure gave a mean recovery of $100 \cdot 2 \%(\mathrm{SD}=5 \cdot 45, \mathrm{n}=7)$. The sodium concentration of the blank square is negligible for practical purposes $\left(5-6 \times 10^{-5} \mathrm{mEq} / 9 \mathrm{~cm} .^{2}\right)$.

\section{Discussion}

The risk, from iontophoresis, of a serious effect on the heart or respiration is small, provided that equipment is used which makes accidental exposure of the patient to large currents impossible. Since the skin resistance may be as high as $50,000 \mathrm{ohms} /$ cm. ${ }^{2}$, a potential difference of 25 volts is required to give a current density of $4 \mathrm{~mA} / 9 \mathrm{~cm} .{ }^{2}$. On the other hand, the skin resistance over a blister or some lesion exuding extracellular fiuid may be $1000 \mathrm{ohms} / \mathrm{cm} .{ }^{2}$ or less, which would give currents of at least $200 \mathrm{~mA}$. It is therefore necessary to ensure that even at a very low skin resistance a current of not more than about $10 \mathrm{~mA}$ can flow through the patient's limb. This can be achieved by means of a resistance of 2700 ohms in series with a 27 volt supply. In addition, a variable resistance of $0-50,000 \mathrm{ohms}$ in series enables the current to be adjusted to $4 \mathrm{~mA}$. During iontophoresis the ammeter must be kept under constant observation since the skin resistance drops substantially when the sweat glands first begin to secrete or if a blister is forming. In the latter case, pain will be experienced and a large proportion of the total current will pass through the relatively small area of the blister, thus leading to escalation of tissue damage and current density.

The experiments described above show clearly that blister formation is due to the low $p H$ which develops as acid products of electrolysis penetrate to the skin. If this is prevented by interposing a thick pad of filter paper, saturated with electrolyte, between the skin and the anode, blisters will not be produced and the patient will usually not complain of pain.

Though a lead or copper anode does not generate as much acid as a carbon electrode, it will give rise to lead or copper ions instead, which may pass into the skin if the thickness of the pad is inadequate.

Evaporation of water from the absorbent paper can result in serious analytical errors. From a 
filter paper square $3 \times 3 \mathrm{~cm}$. it can be as high as $0.3 \mathrm{mg}$. $/ \mathrm{sec}$. Thus, in half a minute $9 \mathrm{mg}$. of water may be lost from $18 \mathrm{mg}$. of sweat collected, and consequently a true sweat sodium concentration of $40 \mathrm{mEq}$ per litre would apparently be well in the CF range. Evaporation may occur during the collection of sweat in a 'chamber' inadequately sealed, on opening the 'chamber', during transfer to the weighing bottle, and from the weighing bottle if its lid does not fit tightly. The danger of loss of water during the collection will be greater the longer the collection period, both by evaporation and by hydration of the skin. The method proposed by Shwachman and Mahmoodian (1966) suffers from this disadvantage.

The importance of an adequate secretory rate can be appreciated from Fig. 3, which shows that at a rate of $15 \mathrm{mg} . / 9 \mathrm{~cm} .^{2}$ per $5 \mathrm{~min}$., or less, the sodium concentration of CF sweat may be well below the usual accepted limit for normal values.

The sweat test may be carried out safely and reliably according to the procedure described below. Little or no pain is experienced by most patients, and the risk of burns or blisters is eliminated. Sufficient sweat can almost invariably be obtained, even from small infants, at an adequate secretory rate and duplicate or triplicate specimens are available with little extra trouble. They are a substantial safeguard against erroneous conclusions due to evaporation of water or contamination of the sweat.

Recommended Procedure. In view of the risk, however slight, of ventricular fibrillation and respiratory arrest, iontophoresis should be carried out with equipment which, on short circuiting, does not give currents in excess of $10 \mathrm{~mA}$. Three 9-volt dry batteries in series with a fixed resistance of $2700 \mathrm{ohms}$ and a variable resistance $(0-50,000 \mathrm{ohms})$ are suitable. Further, the electrodes should always be placed on the same limb to avoid passing the current through the chest.

Adequate secretion rates can be achieved almost invariably, even in small babies, if the patient is kept in a warm room $\left(28-32^{\circ} \mathrm{C}\right.$.) for 30 minutes before and during the stimulation and collection of sweat. Without heating, some subjects find iontophoresis painful, and little sweat is obtained.

The volar surface of a lower arm or leg is most suitable (the density of sweat glands is smaller on the more muscular part of the limb). A site should be selected where there are no visible lesions of any kind. It should be carefully cleaned and dried.

Not less than 10 filter paper squares (Whatman $541,3 \times 3 \mathrm{~cm}$.), should be interposed between the positive electrode and the skin. The papers should be thoroughly wet with pilocarpine nitrate $(0 \cdot 45 \%)$.

The anode may be of carbon, copper, or lead, and should be not less than $2 \times 2 \mathrm{~cm}$ It can be conveniently applied to the arm, stuck to adhesive tape which should be $3 \mathrm{~cm}$. wide. and long enough to be wrapped round the limb. A strip of copper foil folded into muslin or gauze wetted with $0.3 \% \mathrm{~K}_{2} \mathrm{SO}_{4}$ (it is preferable to avoid $\mathrm{Na}^{+}$or $\mathrm{Cl}^{-}$to reduce the risk of accidental contamination) serves as the cathode and is placed above the elbow.

The anode and the stack of filter papers should be affixed to the skin sufficiently firmly to ensure good contact over the whole of the area, but without squeezing out too much of the pilocarpine solution.

A current of $0.5 \mathrm{~mA}$ should be passed for 30 seconds to stimulate mildly as many sweat glands as possible and thus reduce skin resistance evenly and avoid excessive local load. The current should then be increased gradually to $4 \mathrm{~mA} / 9 \mathrm{~cm}$. $^{2}$ which should be maintained for 5 minutes and then reduced slowly.

The stimulated area of skin must be washed well with distilled water and carefully dried with filter paper (Whatman 541).

Immediately after the last dab with filter paper, the site is covered with a $3 \times 3 \mathrm{~cm}$. square of washed $x$-ray film, stuck to a strip of elastic polythene adhesive tape (XS4800, X-lon Products Ltd., London), $5 \mathrm{~cm}$. wide and $15 \mathrm{~cm}$. long, with one edge superimposed on the edge of the celluloid square. Under this square is inserted, by means of forceps, a square of filter paper (Whatman 541, $3 \times 3 \mathrm{~cm}$.) previously weighed and stored in a weighing bottle with tightly fitting lid. Evaporation of water from the collection 'chamber' is prevented by a short strip of polythene tape, $2.5 \mathrm{~cm}$ wide, placed over the opening.

After a suitable interval (see below) the sealing tape is removed while pressing the 'chamber' to the patient's arm; the skin near the opening is quickly wiped with Whatman 541 paper to remove any sweat which may have formed under the sealing tape, and the paper is withdrawn with forceps and quickly transferred to the weighing bottle. The grasping of the paper and its transfer should not take longer than 5 seconds. A second pre-weighed square is introduced and sealed into the 'chamber', and the collection of sweat is continued for an appropriate period. In this fashion two or more samples can be collected and analysed independently. It is important to ensure that while it remains unsealed the 'chamber' is held firmly to the skin by a helper. Her fingers, or the operator's, must not touch the patient's skin near the opening of the chamber.

The secretory rate, as calculated from the amount of sweat collected over the given time, should be not less than $18 \mathrm{mg} . / 9 \mathrm{~cm}^{2}$ per $5 \mathrm{~min}$.

The collection time is chosen according to the appearance of the paper under the $x$-ray square. At a secretion rate of 20 to $25 \mathrm{mg}$. per 5 minutes, the paper will appear uniformly damp after 10 to 15 minutes, and collection should not be prolonged beyond this stage to minimize reabsorption of water by the skin. At higher secretion rates the collection can be stopped earlier. In any case the time should be recorded for the purpose of calculating the secretion rate. 


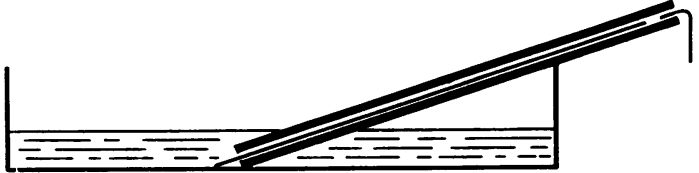

FIG. 4.-Eluting device.

After weighing, the paper square is eluted by one of the standard methods, e.g. by clamping one edge between two perspex plates which dip into a reservoir of water. The water rises to the other end of the plate by capillarity, aided by a filter paper strip acting as a wick, and thence descends through the paper square into a beaker (Fig. 4) (soda glass must be avoided throughout). Between 2 and $3 \mathrm{ml}$. of eluate is satisfactory. The volume is recorded and the sodium is determined in the flame photometer.

\section{Summary}

Safety aspects of the pilocarpine sweat test have been investigated. The maximum current obtainable from the apparatus should not exceed 10 mA. Burns and blisters have been shown to be caused by the penetration of acid, generated electrolytically, to the vicinity of the patient's skin. They can be prevented by interposing a stack of 10-12 filter papers saturated with pilocarpine solution between the skin and the electrode.
Some sources of analytical error have been considered. Evaporation from the collection pad or paper can be rapid, resulting in up to twofold concentration of the sweat in 30 seconds. The method presented in detail has the following merits: it is believed to be safe and causes no burns or pain, it almost invariably yields sufficient sweat, replicate samples are available at little extra trouble, and the reliability of the test is improved.

We are grateful to Dr. W. R. Lee and Mr. S. Zoledziowski for valuable advice, and to the Cystic Fibrosis Research Foundation Trust, the Board of Governors, United Manchester Hospitals, and the Booth Hall and Monsall Hospital Management Committee for financial support.

\section{REFERENCES}

Angelis, A. L., Lee, W. R., and Zoledziowski, S. (1965). Experimental investigation of the effects of direct current electric shock on respiration. Brit. F. industr. Med., 22, 210.

Kench, J. E. (1940). The determination of minute amounts of lead in urine. Biochem. F., 34, 1245.

Kouwenhoven, W. B. (1949). Effects of electricity on the human body. Electr. Engng., 68, 199.

Lee, W. R. (1966). Death from electric shock. Proc. Inst. Elect. Eng., 113, 144.

Rosenberg, E. W., Blank, H., and Resnik, S. (1962). Sweating and water loss through the skin. F. Amer. med. Ass., 179, 809.

Shwachman, H., and Antonowicz, I. (1962). The sweat test in cystic fibrosis. Ann. N.Y. Acad. Sci., 93, 600 .

- and Mahmoodian, A. (1966). The sweat test in cystic fibrosis. A comparison of overnight sweat collection versus the pilocarpine iontophoresis method. F. Pediat., 69, 285. 